\title{
De-Anglicising humour studies
}

\section{Cliff Goddard}

Griffith University, Australia

c.goddard@griffith.edu.au

\begin{abstract}
This Commentary has two main aims. The first is to argue that systematic approaches to "humour" have been hampered and skewed by terminological Anglocentrism, i.e. by reliance on terms and categories which are English-specific, such as 'amusing', 'joking', 'serious', and 'mock', and even by the banner term 'humour' itself. Though some humour scholars have recognised this problem, I contend that they have under-estimated its severity. Anglocentric terminology not only interferes with effective communication within the field: it affects our research agendas, methodologies, and theoretical framings. Needless to say, humour studies is not alone in facing this predicament, which at its largest can be described as the global Anglicisation of humanities and social science discourse.

While calls to make humour studies more conceptually pluralistic are laudable, they cannot fully succeed while 'full' Anglo English remains the dominant scholarly lingua franca. The second aim of this paper is to argue that considerable progress can be made by "deAnglicising English" from within, using a newly developed approach known as Minimal English. This allows re-thinking and re-framing humour terminology and agendas using a small vocabulary of simple cross-translatable English words, i.e. words which carry with them a minimum of Anglo conceptual baggage. For illustrative purposes, I will discuss how complex terms such as 'wit, wittiness' and 'fantasy/absurd humour' can be clarified and deAnglicised using Minimal English.
\end{abstract}

Keywords: humour concepts, Anglocentrism, Minimal English, lexical semantics.

\section{Conceptual Anglocentrism and why it matters for humour studies}

Some scholars may reject the claim that the field of humour studies is Anglocentric, pointing out that there are a great many studies of humour phenomena in non-English languages and that there are, and always have been, a great many non-Anglo researchers in the field of humour studies. But that is not the kind of Anglocentrism I wish to discuss in this Commentary. I am not objecting to any unbalanced focus on the English language as an object of study, but rather to its role as the main descriptive and conceptual metalanguage for humour studies. 
This is the typically unrecognised Anglocentrism against which Wierzbicka (2014) argues in her book Imprisoned in English: The hazards of English as a default language. It may be largely due to the "convenience factor" of English as a scholarly lingua franca, but the consequence is that English-specific linguistic categories end up being treated as if they were neutral, natural, universal, and universally applicable. As Levisen (2019a) puts it, academic Anglocentrism is influencing "the framing of research questions and methods, the analysis of data, the interpretation of results, and the establishment of scholarly discourse and terminologies".

One of Wierzbicka's (2014) most convincing case studies comes from psychology, where an entire theory ("basic emotions theory") has arisen around the historically contingent and hard-to-translate English metacategory of emotion. The theory revolves around Englishspecific lexical categories such as fear and disgust, regardless of the fact that the nearest dictionary equivalents for these words in a language as familiar as German (i.e. Angst and Ekel, respectively) are manifestly different in meaning and usage (Wierzbicka 1999: Ch 6; Goddard 2014). In pragmatics, one thinks of the field of "im/politeness studies", which was started under the banner of the Anglo cultural key word politeness, from which it has never managed to extricate itself. Despite decades of definitional debates and discussions it is arguable that the English folk concept of 'politeness' continues to exert a skewing effect (Ye 2019; cf. Anchimbe 2018: 29-55; Ameka \& Terkourafi 2019).

Sceptics might like to think that it is all "mere terminology", but they should ask themselves: Can one imagine "humour studies" having the same contours as it has today if it had evolved with French, for example, as its leading language? It would be pretty hard to believe so, given that French has no term corresponding closely with English humour (Noonan 2011; Goddard 2017). Admittedly, scholars in humour studies often work with a broader concept in mind (Attardo 2004; Dynel 2018) usually linking the field with being 'amusing', 'jocular', or 'non-serious', or the like. It is known from cross-linguistic studies, however, that none of these terms is a cross-linguistically stable anchor point. On the other hand, we equally know that laughter ('be laughing') is a cross-linguistically stable anchor point and this has led to the proposal that we need to re-frame our conception of the research field, basing it on "social laughter" or "laughing with other people" (Goddard 2017; 2018a; Goddard \& Mullan 2020).

In this Commentary, however, I will not pursue the use of "humour" as a key word in the (inter)disciplinary branding of the field. Rather, I would like to focus attention on the fact that our lower-level descriptive vocabulary is also drawn from English, including literally dozens of hard-to-translate English words: nouns such as 'amusement' and 'wit', speech-act words (both verbs and nouns) such as 'joke', 'tease', 'quip', 'mockery', 'banter', 'sarcasm' and 'repartee', adjectives such as 'serious', 'jocular', 'deadpan', and 'mock'. Often such terms are together used in combination, leading to a proliferation of terms like 'fantasy humour', 'mock abuse', 'deadpan jocular irony', and the like. In addition to non-translatability, there is also a shortfall in conceptual clarity, i.e. the exact intended meaning is often unclear. There is a very real danger that the same terms are being used differently by different authors, and conversely, that similar or identical phenomenon are being described using very different terms.

In this Commentary, I would like to urge, with Levisen (2019a), that the way forward is not to abandon English as a tool for international academic communication, but rather, when descriptive precision is needed, to replace "macro-English - with all its culturally specific concepts - ... [with] a much smaller English, or, a maximally unbiased and deanglicized way of using English ... ." (emphasis added). Essentially, this is a new approach to combating a seemingly intractable problem. 


\section{De-Anglicising English by using simple cross-translatable words: NSM and Minimal English}

The new approach depends on research findings from cross-linguistic semantics - specifically, from research conducted by linguists working in the Natural Semantic Metalanguage (NSM) framework - that all or most languages share a small core of ultimately simple meanings (Wierzbicka 1996; Goddard \& Wierzbicka 2014). These meanings, known as semantic primes, are expressed by words such as (in English): I, you, someone, people, good, bad, want, do, know, think, words, say, because, can, maybe, and about 50 more. These are meanings which resist all attempts at non-circular definition and which, evidence suggests, are expressible by words or word-like units in all or most languages. The full inventory of semantic primes is given in Table 1 at the end of this section. It is presented in English, French, and Finnish. Comparable tables are available in more than 25 other languages from a diversity of language families, geographical locations, and cultural types. ${ }^{1}$

In addition to semantic primes, all or most languages arguably share some hundreds of other basic meanings, themselves definable in terms of semantic primes, which function alongside primes as semantic building blocks in complex meanings. These additional "meaning builders" are known as semantic molecules. They include various parts and aspects of the human body (e.g. 'hands', 'legs', 'head', 'eyes', 'mouth'; 'face' and 'voice'), biosocial categories (e.g. 'men', 'women', and 'children'), physical qualities (e.g. 'long', 'round', 'flat', 'hard', 'sharp'), environment (e.g. 'sky', 'sun', 'ground', 'fire', 'water'), and others. Of particular relevance to humour studies, it is proposed that both 'laugh' and 'play' are universal or near-universal molecules (French rire 'laugh', jouer 'play'; Finnish nauraa 'laugh', leikkiä 'play').

Semantic primes, together with universal or near-universal semantic molecules, comprise the vocabulary which is ideal for the purpose of systematic cross-linguistic semantics; hence, the term Natural Semantic Metalanguage. There is a large NSM bibliography of studies of many languages; see [nsm-approach.net]. The metalanguage of simple cross-translatable words has proved itself as a serviceable tool for linguistic analysis: able to capture subtle similarities and differences between meanings, to enable the analyst to distinguish between distinct meanings of a single word (lexical polysemy) and the effects of contextual enrichment, to explore the interplay between lexical meaning and grammar, to trace processes of semantic change, and many other questions and issues of burning interest to linguists. It has also proved itself capable of capturing many subjective, culture-related and anthropocentric aspects of meaning.

Now here is the key point. Because words with these simple meanings appear to exist in all or most languages, an English whose vocabulary consists of these and other crosstranslatable words can be regarded as a "de-Anglicised English". As such, it can also be used, after some adaptations, to provide a clear, practical, and accessible "communication tool" for non-specialists; for example, in language teaching contexts, intercultural education, health communication, agricultural development training, use with people with cognitive deficits or disorders (Goddard 2018b; in press/2021; Wierzbicka 2018; Hill 2020; Sadow 2019; Jordan 2017). In this capacity, it is usually known as Minimal English.

Minimal English is, of course, only one of an open-ended set of minimal languages (Minimal French, Minimal Spanish, Minimal Chinese, etc.), all of which are based on a shared core of simple, cross-translatable words. The special standing of Minimal English follows

\footnotetext{
${ }^{1}$ https://intranet.secure.griffith.edu.au/schools-departments/natural-semantic-metalanguage/downloads
} 
solely from the role of ordinary 'macro-English' (to use Levisen's term) as a global lingua franca.

The development of Minimal English offers an opportunity to reduce Anglocentrism and at the same time increase precision in scholarly discourse. In section 4 , I will illustrate how this might work in practice for humour studies. Before that however, I would like to underline the extent to which lexical categories really do differ between languages by briefly considering some examples.

Table 1. Semantic primes in three languages: English, French, Finnish [after Goddard \& Wierzbicka 2014; Peeters 2015, Vanhatalo et al. 2014].

\begin{tabular}{|l|l|l|}
\hline $\begin{array}{l}\text { I, you, someone, } \\
\text { something thing, people, } \\
\text { body, kind, part }\end{array}$ & $\begin{array}{l}\text { je, tu, quelqu'un, quelque } \\
\text { chose chose, gens, corps, } \\
\text { kinds, parts }\end{array}$ & $\begin{array}{l}\text { minä, sinä, joku hän, } \\
\text { jokin asia, ihmiset, keho, - } \\
\text { laisia, osat }\end{array}$ \\
\hline this, the same, other else & ce, la même chose, autre & tämä $\sim$ se, sama, muu toinen \\
\hline $\begin{array}{l}\text { one, two, much many, } \\
\text { little few, some, all }\end{array}$ & $\begin{array}{l}\text { un, deux, beaucoup, peu, } \\
\text { certains, tous }\end{array}$ & $\begin{array}{l}\text { yksi, kaksi, muutama, } \\
\text { kaikki, paljon moni, } \\
\text { vähän harva }\end{array}$ \\
\hline good, bad, big, small & bien, mal, grand, petit & hyvä, paha, suuri, pieni \\
\hline $\begin{array}{l}\text { know, think, want, don't } \\
\text { want, feel, see, hear }\end{array}$ & $\begin{array}{l}\text { savoir, penser, vouloir, ne } \\
\text { pas vouloir, sentir, voir, } \\
\text { entendre }\end{array}$ & $\begin{array}{l}\text { tietää, ajatella, tahtoa, ei } \\
\text { tahtoa, tuntea, nähdä, kuulla }\end{array}$ \\
\hline say, words, true & dire, mots, vrai & sanoa, sanat, totta \\
\hline do, happen, move & faire, arriver, bouger \\
\hline $\begin{array}{l}\text { be (somewhere), there is, be } \\
\text { mine }\end{array}$ & $\begin{array}{l}\text { être (quelque part), il y a, } \\
\text { être (quelqu'un/quelque } \\
\text { chose), (est) à moi }\end{array}$ & $\begin{array}{l}\text { olla (jossain), olla, olla } \\
\text { (joku/jokin, (on) minun }\end{array}$ \\
\hline live, die & vivre, mourir & elää, kuolla \\
\hline $\begin{array}{l}\text { time when, now, before, } \\
\text { after, a long time, a short } \\
\text { time, for some time, } \\
\text { moment }\end{array}$ & $\begin{array}{l}\text { quand moment, maintenant, } \\
\text { avant, après, longtemps, peu } \\
\text { de temps, pour quelque } \\
\text { temps, instant }\end{array}$ & $\begin{array}{l}\text { milloin aika, nyt, ennen, } \\
\text { jälkeen, kauan, vähän aikaa, } \\
\text { jonkin aikaa, hetki }\end{array}$ \\
\hline $\begin{array}{l}\text { place where, here, above, } \\
\text { below, far, near, side, } \\
\text { inside, touch }\end{array}$ & $\begin{array}{l}\text { où endroit, ici, au-dessus, } \\
\text { au-dessous, loin, près, côté, } \\
\text { dans, toucher }\end{array}$ & $\begin{array}{l}\text { paikka missä, tässä, päällä, } \\
\text { alla, kaukana, lähellä, puoli, } \\
\text { sisä-, koskea }\end{array}$ \\
\hline $\begin{array}{l}\text { not, maybe, can, because, if, } \\
\text { very, more, like }\end{array}$ & $\begin{array}{l}\text { ne...pas, peut-être, pouvoir, } \\
\text { à cause de, si, très, plus, } \\
\text { comme façon }\end{array}$ & $\begin{array}{l}\text { ei, ehkä, voida, koska, jos, } \\
\text { erittäin, enemmän, } \\
\text { näin kuten }\end{array}$ \\
\hline
\end{tabular}

\section{Words for "laughing with other people" differ greatly across languages}

In the last decade NSM semantics has been starting to turn attention to laughter-related vocabulary in different languages, producing a growing body of studies, albeit so far from a limited number of authors (see Appendix). In my view, the broader humour studies community, including non-linguists, will find it interesting to keep a watching brief on this literature. The primary mode of analysis in the NSM framework is the 'semantic explication'. Essentially, an explication of a word or other expression is a paraphrase of that word or expression, i.e. a way of saying the same thing, composed entirely of simple cross-translatable 
words. If a word has several distinct senses, i.e. a situation of lexical polysemy, each is given a separate explication.

This section presents thumbnail sketches of explications from three languages - French, English, and Farsi (Persian). Their meanings all involve "laughing with good feeling" and in each case it may be claimed that the expressions being explicated are central to the "humourrelated" discourse of their respective languages. In addition to the shared aspects, however, each word has aspects of meaning which make it significantly different from the others - both in its semantic components and in the way the explication is framed or structured. For reasons of space, little evidence or justification can be provided here. It is important to note, however, that all three explications work by depicting a prototypical situation (e.g. 'like people often do when ...'). For a fuller account, see Goddard (2018a), Goddard \& Mullan (2020), and Arab (2020).

Let us begin with French, where the most important verb in this lexical field is arguably plaisanter. Originally, this verb has a broad meaning to do with saying or doing things for "pleasure" without any very close connection to laughing; it is etymologically related to the adjective plaisant 'pleasing' and to the verb plaire 'to please'. However, in contemporary French to say that someone said/did something pour plaisanter 'for plaisanter' is often the closest equivalent to saying (in English) that they said/did it "as a joke", "for fun", "not seriously", etc.

The expression pour plaisanter is explicated, in a typical sentence frame, in [A] below (Goddard \& Mullan 2020: 14). Notice that the explication is significantly "sociable" in two ways: first, it envisages a prototypical situation in which people 'are with some other people for some time' and that 'they feel something good towards these other people at this time'. In this situation, one says or does something pour plaisanter wanting 'people here to feel something good for some time like people often feel when they laugh' (i.e. a feeling close to English "amusement"). The framing is about creating a pleasurable social atmosphere, with shared good feelings, over an extended period of time. Note that the expression 'people here' could include the speaker.

\section{[A] Semantic explication for He said/did it pour plaisanter. [French]}

he said/did it like people often say/do when it is like this:

they are with some other people for some time, they feel something good towards these other people at this time ${ }^{2}$

they think like this:

"I want people here to feel something good for some time

like people often feel when they laugh $[\mathrm{m}] "$

In a wider perspective, the semantics of (pour) plaisanter and other, related French words, such as rigoler 'laugh with others, have fun together', seem to imply that French speech culture is interested in pleasurable social interactions, in people being together, making short spontaneous remarks, sharing the resulting good feelings, and often laughing (cf. Béal \& Mullan 2013; 2017).

Moving now to English: the verb to joke is more speaker-focussed, in the sense that it is about the performance of a speaker who is, or appears to be, motivated to get 'people here' to laugh and feel good for a short time, i.e. it anticipates an "audience reaction". It is explicated in [B] below (Goddard 2018b: 496).

\footnotetext{
${ }^{2}$ Whether the expression 'feel something good towards (someone)' is translatable into all languages has been called into question (cf. Brise 2017) and the matter is under investigation.
} 


\section{[B] Semantic explication for She was joking. [English]}

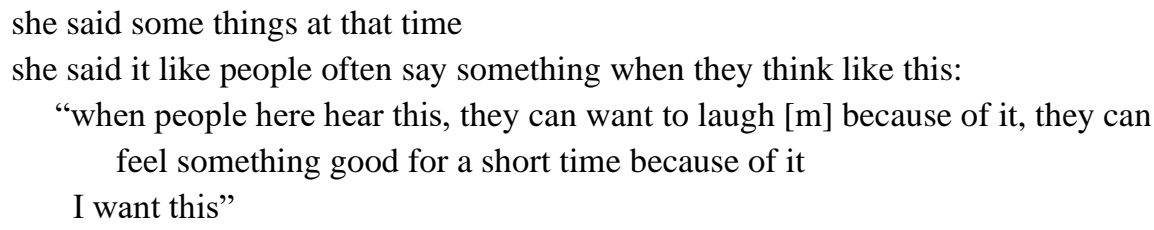

Now to the Farsi (Persian) expression hāzer javābi [lit. ready (with) response] (Arab 2020, fc). Unlike French (pour) plaisanter and English to joke, this is an adjectival expression. It designates one of the most valued and socially desirable personal attributes in Persian culture; roughly, an impressive ability to quickly and skilfully produce an effective verbal response in any situation. Farsi-English dictionaries often gloss it and its derivatives using words like 'quick-wit', 'repartee', and 'quip'. An ethnopragmatic script (in effect, a partial semantic explication) is given in [C] below (Arab 2020: 87).

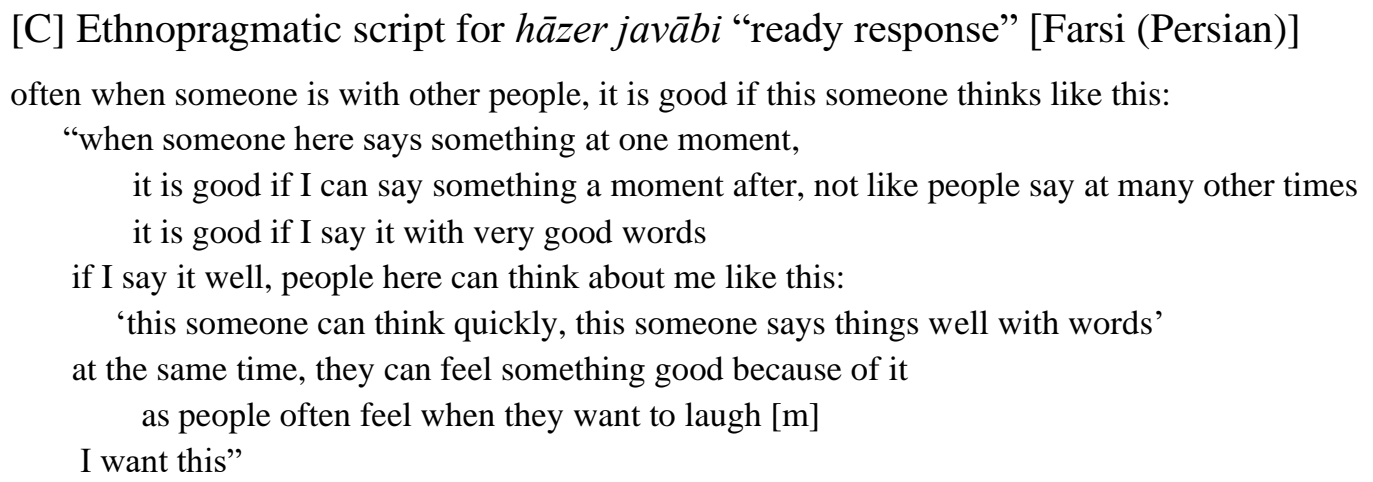

It is part of the meaning of häzer javābi that the audience reaction can include a good feeling of the kind associated with laughter, and the speech of someone with häzer javābi indeed often triggers laughter (laughter of delight). To get this reaction is not main point of being häzer javābi, however: it is more keyed towards evoking admiration.

The purpose of showing the above examples has been to dramatize the point that words matter: that when scholars choose to rely primarily on English words to describe "laughterrelated talk" all around the world, they are accepting certain Anglo framings, perspectives and assumptions that come in-built with these English words; and equally, that in so doing they are closing off alternative framings, perspectives, and assumptions that belong to the words of other languages.

I hasten to add that I am not suggesting that scholars all need to acquire skills in semantic analysis in order to push back against Anglocentric terminology; but we do have to reduce our critical reliance on English-specific terms.

\section{Not relying on untranslatable Anglo words}

To move towards de-Anglicising humour studies, we do not need to stop using Englishspecific terms altogether. That would hardly be possible while still writing in English. What we can do, as Levisen (2019a) puts it, is that: "We can stop relying on them, and we can stop taking them for granted. We might also want to avoid them in all central claims we make, and remove them from core methodologies and basic terminologies" (emphasis added).

Breaking this down into a plan of action, what is needed is: (i) to become more aware of untranslatable, English-specific meanings, (ii) whenever one uses an untranslatable Englishbound term as "basic terminology", to acknowledge and reflect on it, and, preferably, (iii) to 
take the time to explain one's intended sense of it - not using equally complex untranslatable terms (which would only compound the problem), but rather using Minimal English.

There are several additional advantages to such a protocol. Very often when humour researchers deploy English-bound expressions such as 'wit', 'joking', 'mockery', or 'word play' to describe humour-related practices in another language or culture, they do not mean to imply that these English words are perfectly suited to describing the non-English language or cultural practice. Rather, they use these words for convenience - as approximations, heuristics. Essentially, the researcher chooses what they see as the closest available English words to label the phenomenon in question, which they proceed to explore, explain, or analyse with reference to culture-embedded examples. But as mentioned earlier, this opens the possibility that the same terms are being used with different intended meanings by different authors. If so, researchers end up talking at cross purposes.

So, what would it look like if authors were to accept the "de-Anglicising challenge"? Simply put, it means trying to clarify the key idea behind your intended meaning of a term, using a line or two of text written in simple, translatable words. To illustrate, here are two examples for terms which, in my estimation, are often used in the humour literature with differing intended meanings.

I want to emphasise that the "snippets" below are not intended as exhaustive or conclusive in any sense. They are being offered as examples of translatable phrasings that may be useful, in different contexts, to specify what is being meant by terms such as "wit, wittiness" and "absurd/fantasy humour". For brevity, these snippets omit any laughter-related components.

The terms 'wit' and 'wittiness' designate highly favourable judgements about how someone can speak and think, but the exact way in these ingredients are blended, so to speak, may differ from language to language. Three possible interpretations are given in (i)-(iii) below. (i) captures a combination in which someone's speech is admired as an indication that they 'can think very well, ... can think very quickly'. (ii) expresses greater attention to the idea that someone 'can speak very well', backed up by the thought that this implies the ability to think very quickly. (iii) combines quick thinking with a direct mention of a person's skill with words (as implied in the Farsi häzer javābi concept).

\section{Three possible interpretations of "wit, wittiness"}

(i) ... when people hear it, they can think:

"this someone can think very well, this someone can think very quickly"

(ii) ... when people hear it, they can think:

"this someone can speak very well"

"people can't speak like this if they can't think very quickly"

(iii) ... when people hear it, they can think:

"this someone can think very quickly, this someone can say things well with words"

Terms like 'absurd humour' and 'fantasy humour', along with others such as 'fantasising', are currently being used to designate a wide range of practices, from telling "tall tales" to coconstructing "absurd" or "fantasy" scenarios in conversational joking (Béal \& Mullan 2017; Dynel 2018: 409ff). The interpretation given in (i) below depicts someone making ostensibly factual statements about something 'when people can know that it can't be like this'. The version given in (ii) focuses more on narration (i.e. saying many times "something like this happened ..., then something like this happened: ...") and presents a more extreme formulation: 'when everyone knows that things like this can't happen'. The version in (iii) is 
more appropriate for "acting out" scenarios, where the participants pretend to have views and wishes that they clearly do not have; cf. Stallone \& Haugh (2017). (Obviously, additional text would be needed to indicate the "joint", "collaborative", or "escalating" aspects, in cases where people do this together).

Three possible interpretations of "absurdity" and "fantasy"

(i) someone says about something "it is like this: ....", when people can know that it can't be like this

(ii) someone says many times "something like this happened: ..., then something like this happened: ...", when everyone knows that things can't happen like this

(iii) something says about something "I think like this about it, I want to do something because of it", when everyone knows that it is not like this

These examples are not intended to be prescriptive in any sense; nor would I claim that they correspond precisely to the intended meanings of particular authors who have employed terms such as 'wit' or 'absurd/fantasy humour'. They are simply offered to give a sense of what it might look like if authors were prepared to spare a few lines in their research studies clarifying their terms using Minimal English.

To reiterate, the two main guidelines for trying to de-Anglicise humour studies discourse are, first, to reduce critical reliance on English-bound terminology, and, second, if and when using such terminology to gloss and clarify one's intended sense using Minimal English.

\section{Concluding remark}

The purpose of this Commentary has been to highlight the problem of conceptual Anglocentrism and to propose a way to "push back" against it, using the newly developed tool of Minimal English. As I see it, the necessary actions are not particularly onerous and the benefits would be considerable: (i) increased accuracy, due both to reducing the Anglo distortion and to increasing the precision and granularity of analyses, (ii) better communication within the humour studies community, and (iii) potentially, improved comparability between studies.

It would be naïve to imagine that Anglocentrism can be eliminated altogether, but we should do what we can.

\section{Acknowledgements}

I would like to thank Anna Wierzbicka, Kerry Mullan, and Reza Arab for helpful input to this study, as well as two reviewers for EJHR. 


\section{Appendix}

Humour-related studies using NSM-informed non-Anglocentric terminology

\begin{tabular}{|l|l|}
\hline Topic (words explicated given in italics) & Study \\
\hline $\begin{array}{l}\text { English: being serious, taking something/oneself } \\
\text { seriously }\end{array}$ & Goddard 2009 \\
\hline $\begin{array}{l}\text { English: funny, amusing, humour; jocular abuse, deadpan } \\
\text { irony, jocular deception/provocation }\end{array}$ & Goddard 2017 \\
\hline English: joking, kidding, teasing; just kidding & Goddard 2018a \\
\hline English: laid back, easy-going, irreverent & Goddard \& Cramer 2016 \\
\hline English sarcasm, Danish: sarkasme, sarkastisk humor, & Goddard \& Levisen, \\
dumsmart & forthcoming \\
\hline English: joking, French: rigoler, plaisanter & Goddard \& Mullan 2020 \\
\hline Bislama: giaman & Levisen 2016 \\
\hline Danish: humor, sort humor & Levisen 2018 \\
\hline Danish: hoeho, tøhø (laughter interjections) & Levisen 2019b \\
\hline Danish: fed humor, sort humor, plat humor, syg humor & Levisen 2019c \\
\hline Chinese: ironic bèi-construction & Ye 2019 \\
\hline Farsi (Persian) hāzer javābi & Arab 2020, forthcoming \\
\hline French: blague, blaguer & Waters, this volume \\
\hline
\end{tabular}

\section{References}

Ameka, F. K. \& Terkourafi, M. (2019). 'What if? Imagining non-Western perspectives on pragmatic theory and practice'. Journal of Pragmatics 145, pp. 72-82.

Anchimbe, E. A. (2018). Offers and Refusals. A Postcolonial Pragmatics Perspective on World Englishes. Amsterdam: John Benjamins.

Arab, R. (2020). 'Ethnopragmatics of hazer javabi, a valued speech practice in Persian', in Mullan, K., Peeters, B. \& Sadow, L. (eds.), Studies in Ethnopragmatics, Cultural Semantics, and Intercultural Communication. Vol 1: Ethnopragmatics and Semantic Analysis, Singapore: Springer, pp. 75-94.

Arab, R. (forthcoming). To Be with Salt, To Speak with Taste: Metapragmatics of Playful Speech Practices in Persian. PhD thesis. Griffith University.

Attardo, S. (2004). Linguistic Theories of Humor. Berlin: Mouton De Gruyter.

Béal, C. \& Mullan, K. (2013). 'Issues in conversational humour from a cross-cultural perspective: Comparing French and Australian corpora', in Peeters, B., Mullan, K. \& Béal, C. (eds.), Cross-Culturally Speaking, Speaking Cross-culturally. Newcastle upon Tyne: Cambridge Scholars, pp. 107-140. 
Béal, C. \& Mullan, K. (2017). 'The pragmatics of conversational humour in social visits: French and Australian English'. Language and Communication 55, pp. 24-40.

Brise, L. (2017). Eating Regret and Seeing Contempt: A Cognitive Linguistic Approach to the Language of Emotions in Igala (Nigeria). Frankfurt: Peter Lang.

Dynel, M. (2018). Irony, Deception and Humour: Seeking the Truth about Overt and Covert Untruthfulness. Mouton de Gruyter. [Esp. pp. 388-421]

Goddard, C. (2009). 'Not taking yourself too seriously in Australian English: semantic explications, cultural scripts, corpus evidence'. Intercultural Pragmatics 6 (1), pp. 29-53.

Goddard, C. (2014). 'On "Disgust"', in Baider, Fabienne \& Cislaru, Georgeta (eds.) Linguistic Approaches to Emotions in Context, Amsterdam: John Benjamins, pp. 73-98.

Goddard, C. (2017). 'Ethnopragmatic perspectives on conversational humour, with special reference to Australian English'. Language \& Communication 55, pp. 55-68.

Goddard, C. (2018a). "“Joking, kidding, teasing": Slippery categories for cross-cultural comparison, but key words for understanding Anglo conversational humour'. Intercultural Pragmatics 15 (4), pp. 487-514.

Goddard, C. (ed.) (2018b). Minimal English for a Global World: Improved Communication Using Fewer Words. London: Palgrave. [esp. Ch 3, pp. 29-70, 'Minimal English: The science behind it']

Goddard, C. (ed.) (In press/2021). Minimal Languages in Action. London: Palgrave.

Goddard, C. \& Cramer, R. (2016). "Laid back" and "irreverent": An ethnopragmatic analysis of two cultural themes in Australian English communication', in Carbaugh, D. (ed.), Handbook of Communication in Cross-Cultural Perspective, London: Routledge, pp. 89103.

Goddard, C. \& Levisen, C. (forthcoming). 'Metapragmatics and shifting meanings of "sarcasm" in English and Danish'. [Under review]

Goddard, C. \& Mullan, K. 2020. "Explicating verbs for "laughing with other people" in French and English (and why it matters for humour studies)'. Humor: International Journal of Humor Research 33 (1), 55-77. Doi: 10.1515/humor-2017-0114.

Goddard, C. \& Wierzbicka, A. (2014). Words and Meanings. Lexical Semantics Across Domains, Languages and Cultures. Oxford: Oxford University Press.

Hill, D. (2020). 'From expensive English to Minimal English', in Sadow, L., Peeters, B. \& Mullan, K., (eds.), Studies in Ethnopragmatics, Cultural Semantics, and Intercultural Communication. Vol 3: Minimal English (and Beyond), Singapore: Springer, pp. 33-52.

Jordan, P. (2017). How to Start, Carry On, and End Conversations. Scripts for Social Interaction for People on the Autism Spectrum. London: Jessica Kingsley Publications.

Levisen, C. (2016). 'The ethnopragmatics of speech acts in postcolonial discourse. Truth and trickery in a South Pacific tale', in Schubert, C. \& Volkmann, L. (eds.), Pragmatic Perspectives on Postcolonial Discourse: Linguistics and Literature, CSP, Newcastle Upon Tyne, pp. 41-64.

Levisen, C. (2018). 'Dark, but Danish: Ethnopragmatic perspectives on black humor'. Intercultural Pragmatics 15 (4), pp. 515-531.

Levisen, C. (2019a). 'Biases we live by: Anglocentrism in linguistics and cognitive sciences'. Language Sciences 76. doi.org/10.1016/j.langsci.2018.05.010.

Levisen, C. (2019b). 'Laughter interjections'. Scandinavian Studies in Language 10 (1). Available: https://tidsskrift.dk/sss.

Levisen, C. (2019c). 'Linguistic worldviews and the cultural semantics of humour: A case study on Danish untranslatables', in Głaz, A. (ed.) Languages - cultures - worldviews. Focus on translation, London: Palgrave Macmillan, pp. 319-346.

Levisen, C. \& Waters, S. (eds.). (2017). Cultural Keywords in Discourse. Amsterdam: Benjamins. 
Mullan, K. \& Béal, C. (eds.) (2018). 'Conversational humour: Forms, functions and practices across cultures'. Special issue of Intercultural Pragmatics, 15(4).

Sadow, L. (2019). An NSM-based Cultural Dictionary of Australian English: From Theory to Practice. PhD thesis, Australian National University.

Stallone, L. \& Haugh, M. (2017). 'Joint fantasising as relational practice in Brazilian Portuguese interactions'. Language \& Communication 55, pp. 10-23.

Vanhatalo, U., Tissari, H. \& Idström, A. (2014). 'Revisiting the universality of Natural Semantic Metalanguage: A view through Finnish'. SKY Journal of Linguistics 27, pp. 6794.

Waters, S. (this volume). 'The lexical semantics of blague and blaguer: French ways of bringing people together through persuasion, deception and laughter'.

Wierzbicka, A. (1996). Semantics: Primes and Universals. New York: Oxford University Press.

Wierzbicka, A. (1999). Emotions Across Languages and Cultures. Cambridge: Cambridge University Press.

Wierzbicka, A. (2014). Imprisoned in English: The Hazards of English as the Default Language. New York: Oxford University Press.

Wierzbicka, A. (2018). 'Minimal English as a new and transformative tool for effective health care communication in English-speaking countries'. Paper at International Symposium for Communication in Health Care, Australian National University, 13 February 2018.

Ye, Z. (2018). 'The emergence of expressible agency and irony in today's China: A semantic explanation of the new bèi-construction'. Australian Journal of Linguistics 39 (1), pp. 57 78.

Ye, Z. (2019). 'The politeness bias and the society of strangers'. Language Sciences 76, 101183. Doi: 10.1016/j.langsci.2018.06.009. 